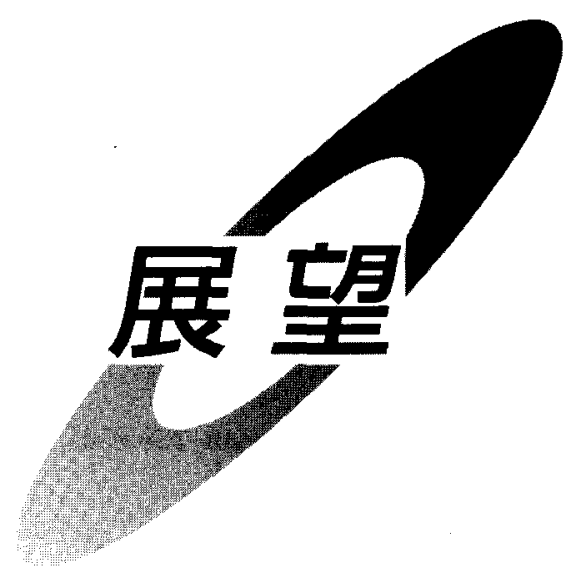

\title{
電気化学で 新たな技術の創出
}

まず私がお引き受けしている北陸支部の活動について述べさせて頂きます。

北陸支部は, 昭和 35 年 10 月折しも戦後の高度成長が始まった時期に, 当時安価で豊富な水力電源を利用し電 気化学関係工場が活況を呈していた北陸の地に設立され，今年で 37 年目を迎えることになりました。この間，昭 和 40 年代末から 50 年代始めにかけて 2 度に渡るオイルショックで, 私も係っていたアルミニウム精練等の撤退 により，支部内の産業構造も大きく変化を遂げて来ています。

北陸支部における主たる活動は，春と秋の大会であります。春季大会は, 毎年 5 月に開催し, 特別講演会と工 場見学会を行っています。本年度は, 富山で開催致しましたが, 特別講演会は, 最近の表面処理技術の動向と企 業戦略の有り坊んいて講演を頂きました. 工場見学会は，工作機械メーカーの協力を得て行い，貴重な情報交 換等が出来ました.

秋季大会は, 研究発表会が重要な活動の一つであります，大学側に加えて産業界からも積極的に参加して頂い ております。一昨年 9 月に二日間に亘り金沢で開催致しましたが，一日目は，研究発表会と特別講演会を行い， 二日目は，電気部品及び纎維関係企業の 2 社の見学会を開催致しました.

ところで最近は，エレクトロニクス，エネルギー変換，バイオテクノロジー等幅広い先端技術分野において電 気化学の原理, 手法が応用され新しい技術が次々と創出されています。従来は, 電気化学と言うと公害対策に苦 虑した分野でありますが, 最近では環境改善に大きく貢献する技術となって来ていると考えております。例えば， 電気自動車用電池開発などは, エネルギー問題, 環境問題等極めて重要な地球規模のテーマとして大きな期待が 持たれています，現在全世界で各種の電池について研究開発が日夜積極的に進められていますが，実用化実験を 兼ねた自動車レースが各地で行なわれるなど, 大きな話題を集めています，又，最近では電気化学を利用した水 のクリーン化技術等バイオテクノロジーの面での発表もされ，実用化されて来て います。

この様に電気化学が従来考えられなかった様な新しい分野に応用され，環境問 題も含めて将来のニーズに応える様になって来たと考えています，従って従来に も增して益々重要な研究分野となって来ており，将来に向けて大いに発展性が有 ると考えております。昨年 10 月長岡で行なわれた電気化学会全国大会に於いて も数々の興味哚い発表が行なわれました。

幅広く 21 世紀に向けて発展する電気化学分野の研究活動の活性化と技術開発 の加速化に寄与できる様に, 産業界からも研究材料の提供等も含め大いに貢献し たいと考えております。

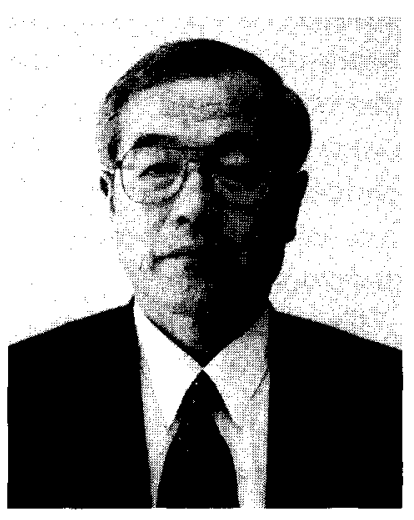

Kunihiko MORI 北陸支部支部長, 理事 三菱化学侏直江津事業所 事業所長 